'It doesn't really matter which university you attend or which subject you study while abroad." The Massification of Student Mobility Programmes and its Implications for Equality in Irish Higher Education.

Pre-publication version - published in the European Journal of Higher Education Aline Courtois*

* Institute of Education, University College London, United Kingdom

A.courtois@ucl.ac.uk

Aline Courtois is a Research Associate in the Centre for Global Higher Education, University

College London Institute of Education. She was previously a Research Fellow at the National University of Ireland, Dublin. 


\title{
"It doesn't really matter which university you attend or which subject you study while abroad." The Massification of Student Mobility Programmes and its Implications for Equality in Irish
}

\section{Higher Education.}

\author{
Based on documentary analysis and interviews, the article examines the current \\ practices of Irish universities in their efforts to increase their students' \\ participation in international exchange programmes. It argues that increased \\ participation, while a positive outcome, obscures a growing differentiation in \\ the types of exchange programmes and destinations. This emerging \\ stratification leads to differentiated experiences and outcomes, which may \\ amplify other forms of stratification pervading the higher education sector. In \\ particular, we look at the emergence of different models of exchange, that have \\ moved away from an academic focus towards a more easily manageable model \\ better suited to the massification underway. We suggest that Irish higher \\ education institutions contribute to making credit mobility a space, where \\ students can deploy socially unequal strategies and where the more vulnerable \\ remain either excluded, or limited to 'second best' programmes, devalued \\ academically or where pedagogic opportunities are lost. This is one of the \\ manifestations of the production of internationalisation under the pressures of \\ cost-saving, corporatisation and the employability discourse.
}

Keywords: internationalisation; student mobility; employability; Ireland; inequality

\section{Introduction}

Since its inception in 1987, the Erasmus exchange programme has played a central role in the expansion of student mobility within Europe. The European Commission is keen to increase the reach of the programme and to double mobility figures by 2020 (EC 2011). Yet this focus on increasing numbers carries risks. Studies of the expansion of higher education systems have shown that under the conditions of 'massification' (broadly defined as a shift from elite to mass participation in higher 
education), higher education institutions (HEIs) and programmes become increasingly differentiated, with some maintaining selectivity and prestige while others - more specifically those absorbing the increased numbers of less privileged and firstgeneration students - become devalued (e.g. Marginson 2016). In contexts where the emphasis is on increasing participation quantitatively, inequality is in fact reproduced, in a different shape, under the combined effect of institutional and individual strategies. Therefore, in times when national and European policies are encouraging a massification of exchange programmes, it seems necessary to examine what this massification looks like. Based on documentary analysis and interviews, this paper discusses the massification of outgoing credit mobility (namely mobility for credit, rather than for a whole degree) in Ireland. It pays specific attention to institutional processes and practices and to the role they play in shaping the field of outgoing credit mobility. In particular, we look at the emergence of models of exchange, that have moved away from an academic focus towards more easily manageable formats better suited to the massification underway. The paper draws attention to some of the possible consequences of a shift in focus from cultural/pedagogic to economic/quantitative considerations in the management of mobility programmes at institutional level. It questions the assumption that increasing student mobility quantitatively somehow automatically enhances the benefits for all. In particular, it points to the unequal benefits generated by current institutional practices, and the risk that these practices reproduce existing inequalities in higher education. Answering the call to articulate issues of geographic mobility and social mobility in higher education (Fernex, de Vries \& Lima 2017), it emphasises the need to rethink current frameworks and hopes to inform the way institutions think internationalisation.

Unlike other studies, this article focuses on credit rather than degree mobility; 
goes beyond measures of participation versus non-participation; and shifts the focus from individual to institutional strategies. Degree (or 'spontaneous') mobility is typically examined from the perspective of either the "push-pull" or the "college choice" framework (Beerkens, Souto-Otero, de Wit \& Huisman 2016). In both frameworks, and in particular the latter, it is understood that privileged strategies are central: By investing in international mobility, the more privileged may acquire prestigious credentials and signal that they are more 'internationalised' than their static peers. As noted by many researchers across the world, these socially unequal strategies both amplify and reconstruct inequality in higher education (e.g. Brookes \& Waters 2009; Kim 2015). As far as credit mobility is concerned, studies have consistently shown that participation remains socially unequal (Geehards \& Hans 2013; Netz \& Finger 2016). But too few studies look beyond the issue of participation versus non-participation or take into account the stratification that exists within credit mobility. ${ }^{1}$

One reason for this frequent oversight is that the space of credit mobility is understood as more limited in terms of the range and extent of strategies students can deploy. Erasmus students are more homogeneous socially, and in terms of their age, and academic level, compared to the much more eclectic population engaged in degree mobility (Erlich 2012). Thus, the 'globally mobile "elite"” would logically opt for degree rather than credit mobility, unless they are already registered at a 'worldclass' university in their home country (Foskett 2010, 120; Brookes \& Waters 2009). Furthermore, degree mobility flows owe largely to movements from countries with underdeveloped higher education systems towards countries with better provision,

\footnotetext{
${ }^{1}$ Magali Ballatore's work examines these processes in her comparative study of France, Italy and the UK (e.g. Ballatore 2013).
} 
while credit mobility is, at least in principle, premised on the principle of equivalence between the sending and receiving institutions. This leads Wächter to argue that degree mobility is vertical, and credit mobility horizontal (Wächter 2014). Concretely, compared to degree mobility, credit mobility has less impact on credentials (students may mention their host university on their CV but will still be graduates from their home university) and requires fewer economic and social resources. The sharp status differentiation between universities on the 'global higher education market' is understood to motivate socially unequal strategies in the realm of degree mobility (Rivzi 2011; Sidhu 2006). However, as far as intra-European credit mobility is concerned, lifestyle and consumption have been found to play an equally important role in students' decisions to become internationally mobile (Rodriguez, Bustillo Mesanza \& Mariel 2011; Van Bouwel \& Veugelers 2013) - although such seemingly non-instrumental motivations are also manifestations of class privilege (Waters \& Brooks 2010). Importantly, credit mobility is largely framed by institutional logics and practices. These limit the scope for individual strategic decision-making in various ways: University partnerships determine the range of destinations on offer; programme structures may or may not allow credit mobility; selection procedures in the home university may limit or regulate access; in some cases, destinations are allocated by staff with limited input from students. Therefore, as an arena where the privileged can deploy decisive strategies of distinction, the space of credit mobility is indeed relatively constrained compared to that of degree mobility.

However, beyond individual decisions, and how these are shaped by structural factors, we need to focus more closely on the influence of institutional frameworks and strategies in shaping credit mobility. The article argues that in the case of Ireland, new institutional approaches to increasing outgoing numbers may contribute to 
producing stratification within the relatively narrow space of credit mobility. After locating these changes in the broader context of the ongoing transformation in European higher education, the article examines institutional approaches to mobility in Ireland. The last section explores the differentiated experiences and outcomes resulting from the emerging stratification of credit mobility programmes.

\section{Methodology}

The article draws on Irish national and institutional policy documents, mobility figures, as well on the results of a qualitative questionnaire completed by students engaged in or returning from exchange $(\mathrm{N}=110)$ and semi-structured interviews with administrative and academic staff $(\mathrm{N}=10)$ and with students $(\mathrm{N}=22)^{2}$ conducted as part of a project entitled "The Significance of International Mobility in Students' Strategies at Third Level” under the NUI Dr Garret FitzGerald Post-Doctoral Fellowship in the Social Sciences from 2014 to 2016. The questionnaire was circulated in four HEIs and included a mix of close-ended and open-ended questions on a broad range of topics, including students' academic experiences. It was used primarily as a scoping exercise to identify trends unexamined in student surveys. Its qualitative design was intended to elicit detailed, reflexive responses rather than to achieve a high participation rate. The in-depth interviews were conducted with students returning from a year abroad. They explored various aspects of the experience abroad as well as the decision-making process, previous experiences of mobility, family background, future study, mobility and career plans. Student participants were recruited from Ireland's seven universities through personal and professional contacts, at university events where they presented their experience, and

\footnotetext{
${ }^{2}$ All participants have been de-identified.
} 
among the questionnaire respondents who had agreed to take part in follow-up interviews. They were recruited across a range of disciplines and destinations and equally from both genders. Staff participants were recruited from five sites both through professional and personal contacts, rather than through top-level management, as the study was interested in the work and perceptions of frontline staff engaged in the management of mobility on a daily basis and the possible tensions between these and institutional discourses and strategies.

The qualitative design makes possible an examination of experiences rarely reported in quantitative surveys. Results are not generalisable; however, the study has significance for other systems undergoing similar pressures. Further studies in Ireland and beyond would benefit from an examination of practices in other institutions as well as their variations from one discipline to the other; in particular, the role of faculty in shaping these processes would deserve more attention.

\section{Background: The commercial and 'professional' turn in higher education and student mobility}

While internationalisation may be understood as an institutional response to outside forces, it is also argued that universities shape internationalisation at least as much as they are shaped by it (Matus \& Talburt 2009) and that they mediate national policy according to their own needs, capacities, status and institutional identities (Stensaker, Frølich \& Gornitzka 2008; Paradeise \& Thoenig 2015). Institutional drivers for internationalisation are varied and include the need to generate income through fees, international branding, strategic alliances, faculty development, quality enhancement and knowledge production (Knight 2006). However, in contexts where universities seek new revenue streams to compensate for the loss of state funding, commercial 
motivations tend to dominate internationalising agendas (Ball 2012; Robertson 2010). In addition to their implications for equity, a risk identified with such approaches is that internationalisation remains a superficial phenomenon, visible in numbers and figures only, rather than the transformative phenomenon it has the potential to be (Turner \& Robson 2008).

Arguably the commercial turn in internationalisation is favoured by circumstances in which universities are required to adopt corporate, profit-seeking behaviours if they are to survive at all. International rankings have also profoundly affected the way universities organise their priorities, steering them further towards competitive behaviours (Lynch 2015). In addition, the mission of higher education is increasingly harnessed to economic goals and dictated by the needs of globalised capitalism (Brown \& Tannock 2009; Li \& Lowe 2015). This shift is discernible in the language of the EU around student mobility, as this example taken from documentation relative to the Erasmus programme illustrates:

Education and training are now more important than ever for innovation, productivity and growth, especially in the context of the current economic and financial crisis, and yet the potential of Europe's human capital remains underexploited. More needs to be done to ensure that education and training systems deliver the knowledge and skills needed in an increasingly globalised labour market... (EC 2011, 2).

In this framework, student mobility is constructed as a pathway to increased labour mobility, a supposed remedy to youth unemployment and low competitiveness. The language of extended access, compatible with the concepts of human capital and the knowledge economy, has replaced that of social justice (Hadfield \& SummerbyMurray 2016), legitimating the current trend towards a massification of access to mobility. 
This represents a significant departure from the original mission of the Erasmus programme. Social justice was a central preoccupation of Corradi, one of the key figures behind the creation of the Erasmus programme. Her vision was that of a widely available and subsidised system of inter-university exchange allowing all willing participants to benefit from a cultural experience at no additional cost (Nørgaard 2014). This system, based on the notion of mutual recognition, was designed to enhance the cultural experience by exposing students to a familiar academic content filtered through different local norms and in a different setting. Typically, therefore, students would take up courses abroad that would be recognised by their home institution. For these reasons, at least in its traditional form, the Erasmus exchange programme offered a relatively affordable way to acquire international capital, without compromising academic progress or incurring the larger costs associated with a gap year or additional year of study. Yet, as the broader phenomena changing the mission of higher education impact on the local, this foundational model is now challenged within Irish institutions.

\section{From policy to implementation: Irish university practices}

\section{Irish universities promoting outgoing mobility}

At national level, the policy for the internationalisation of higher education is broadly in line with a commercial approach, namely one focused primarily on bringing in feepaying students as a source of revenue (Courtois 2016, 2017; Khoo 2011). As in the UK, outgoing mobility has only recently become an explicit strategic goal. It is framed in terms of employability, human capital and national competitiveness (Brooks, Waters \& Pimlott-Wilson 2012; Courtois 2017). 
Quantitative mobility objectives have recently been negotiated between the Higher Education Authority and individual institutions in a further move towards a performance-based funding model. In addition, Irish higher education institutions are chronically understaffed (Courtois \& O'Keefe, 2015) and faced with severe capacity issues - with student accommodation also at a premium: Increasing outgoing numbers is also a way of easing this pressure. Erasmus is a convenient channel for this due to the existence of surplus places: Given the relatively dominant position of Ireland (one of two English-speaking destinations, and perhaps the only one after Brexit), Irish HEIs receive more Erasmus students than they send out (7,216 versus 3,029 under the 2014 Erasmus call [EC 2015, 22-23]). .

In order to increase outgoing numbers, institutions have implemented a range of strategies. All seven universities have fully staffed international offices, which centralise the promotion and management of student mobility. In UCD, the international office holds regular events and information sessions, where various destinations and exchange schemes are promoted in turn. Information and contact emails are readily available on websites. Students returning from exchange are hired either as volunteers or as part-time workers to help promote exchange to their peers. This contributes to create a "culture of mobility" (Beech 2014) on Irish campuses. Irish participation remains only slightly over the European average, and staff express their frustration with what they perceive as a lack of interest in exchange on the part of their students. The attrition rate is a particularly vexing issue for both administrative and academic staff involved in exchange, as they report that many students begin the application process only to drop out at a later stage - often, as reported by interviewed staff, for financial reasons. 
Overall, outgoing figures have increased significantly, in line with the increase observable in other EU countries. Detailed figures available for the period 2002-2003 to 2012-2013 indicate that the increase is partly due to the emergence of Erasmus work placements from the year 2007 onwards. In 2002-2003, 1,626 Irish students participated in Erasmus. They were 2,762 in 2012-13 but this figure included 786 students on work placements. Internships thus accounted for 75 percent of the increase in numbers over the period. The increase is also due to the rise of relatively marginal and/or English-speaking destinations. The numbers going to the more 'traditional' destinations for students of Modern Languages (Spain, Belgium, France, Italy, Germany, Austria, Portugal) decreased slightly over the period. By contrast, numbers going to English-speaking countries (including countries, where English is spoken by a significant proportion of the population, and where courses in English are offered), either as students or interns, increased significantly. ${ }^{3}$ This suggests that the increase in outgoing numbers has taken place at the same time as a diversification of destinations and a move away from the traditional academic, language-focused type of exchange. ${ }^{4}$ As the number of students choosing to study Modern Languages is unlikely to increase dramatically; the programme needs to reach into other department and faculties, drawing in students who may only speak English, and have no a priori academic motivation to undertake study abroad. These figures and observations may not paint a very clear picture; yet, they are consistent with the specific approaches to mobility taken at institutional level, which we will now turn to.

\footnotetext{
${ }^{3}$ Based on figures retrieved from http://ec.europa.eu/education/library/statistics/ay-12-13/facts-figures_en.pdf.

${ }^{4}$ Irish students also have access to non-EU exchange but no consistent figures are available.
} 


\section{A la carte Erasmus? Different models and structures for the year abroad}

The structure of the Erasmus year abroad, as originally envisioned by Corradi, is one where participation is entirely voluntary and where courses taken abroad are fully recognised by the home university as integral components of the overall programme. In this section, this model is referred to as the 'original Erasmus model' in order to compare it with emerging formats.

In several universities, the structure of programmes has been altered, at university level, to 'make space' for a term or full year abroad. Thus, in one university - UL, an additional year has been added to a broad range of undergraduate programmes. This additional year is split in two: an internship in industry in the first semester; and study abroad in the second semester. It is mandatory for students to take part. In both UCD (the largest Irish university) and MU, students may take a full year abroad and turn their three-year degree into a four-year 'international' degree (BA International), if they wish to do so. In both cases, the year is additional to the degree, and typically assessed on a pass/fail basis, rather than being integrated to the academic content of the course.

It is difficult to assess which of these various initiatives has been the most successful in increasing outgoing numbers. However it is worth noting that the university, which has made exchange mandatory, is the biggest sender of Erasmus students in spite of being only the sixth HEI in size. ${ }^{5}$ Both these approaches depart from with the principles of 'mutual recognition' (or even equivalence) at the core of Erasmus, since the modules studied abroad are additional to those studied in the home university. In addition, in both cases, students need to finance an additional year in

\footnotetext{
${ }^{5}$ In 2013-14 (most recent available figures), UL sent 504 students on Erasmus; while the second sender, UCD, sent 391. Figures retrieved from http://ec.europa.eu/dgs/education_culture/repository/education/library/statistics/2014/erasmus-sendinginstitutions_en.pdf
} 
college, which again deviates from the principles guiding the project in its original form. Further, the modules studied in the host university may or may not be related to the student's chosen course. Given the significant resources required to identify equivalent modules and transfer grades, and given the relative scarcity of Englishspeaking courses in Europe for monolingual students, this approach makes it easier to 'massify' and manage outgoing mobility.

These efforts have led to much diversification in the way exchange programmes are managed both within and across institutions. The next table and figure help understand the logics that underpin this diversification.

Table 1 gives an overview of the variations in terms of the duration of the period spent abroad, the destination and module choice requirements, the level and modalities of selectivity, the assessment methods and who handles the exchange.

Table 1. The differentiation in the organisation of the year abroad

\begin{tabular}{lll}
\hline Duration & - & One semester in lieu of semester at home university (3-year \\
& programme) \\
& - & One semester (combined with a one-semester long \\
& internship); integrated (4-year programme) \\
& - & One year, integrated (4-year programme) \\
& - & One add-on year, optional (3-year programme becomes 4- \\
& & year programme: 'BA international') \\
Destination & - & Limited to countries where target language is spoken \\
choice & & (language students, business and languages, European \\
& & studies) \\
& - & No specific requirement \\
\hline Selectivity & - & First-come first-served \\
& - & Competitive (grade-based) \\
& - & Random or unknown \\
\hline Module & - & Close fit organised by faculty \\
choice & - & Close fit required but organised by students \\
& - & Loose fit (e.g. general subject area or taught through target \\
& & language) \\
& - & No specific requirement \\
\hline Assessment & - & Pass-fail \\
& - & Grades taken into account in final grade calculation \\
\hline Handled by & - & Work re-examined at home institution (rare) \\
\hline
\end{tabular}


- International office in partnership with faculty

- International (administrative staff) coordinator based in the School/Department (Business; Law faculties)

- Mainly faculty

Table 1 makes discernible the emergence of practices that potentially undermine the academic nature of the exchange. Destinations may be chosen or assigned randomly regardless of academic considerations; modules may not be matched; students' work may not be monitored or graded; faculty may not be involved. This is consistent with a move away from an academic/cultural focus, and a greater emphasis on lifestyle and employability as justifications for student mobility.

Figure 1 attempts to 'make sense' of this diversification by classifying the possible combinations, or models, in four types according to the level of subject or discipline-specific focus (or level of integration to the academic curriculum) on the vertical axis, and according to the voluntary or mandatory nature of the participation (or level of integration to the programme in an administrative perspective) on the horizontal axis.

Figure 1. Four types of exchange

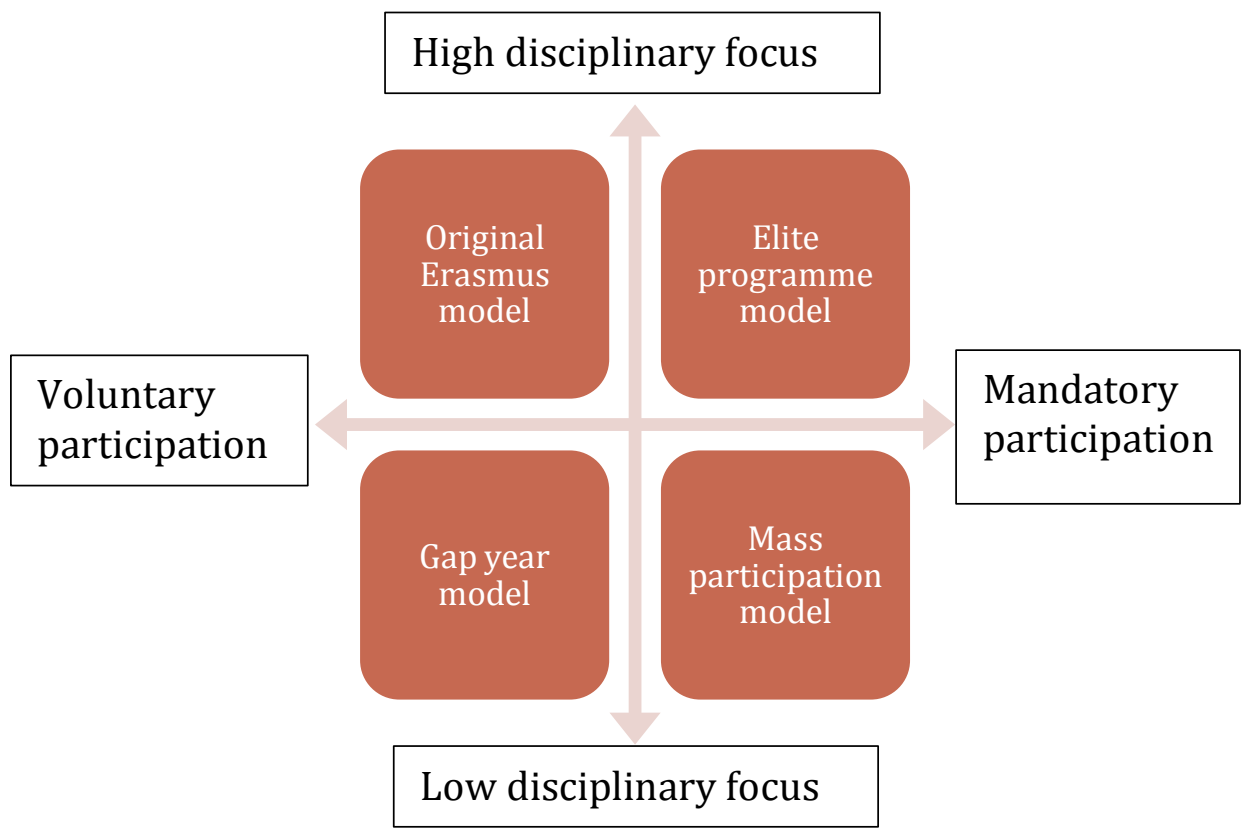


The 'original Erasmus model', close to the model originally proposed by Corradi, is characterised by high curriculum integration (closely matched modules) and low programme integration (participation is voluntary). Due to the module match requirement, partnerships need to be mediated and closely monitored by faculty. The principle of mutual recognition is at play, and in theory, the grades attributed by the host university are transferred to the home university.

In the 'elite programme model', participation is mandatory, as the year abroad is built into the programme. In other words, an international experience is considered as an integral component: this would identify the programme as a relatively 'elite' one, for those with international career aspirations, but in a way that differs from the more vocationally oriented model we will describe last. The year abroad is also justified on an academic basis, by being closely integrated to the curriculum in terms of module match and language of tuition.

By contrast, the 'gap year model' is one where participation is voluntary but where modules are loosely matched or where students are free to choose whichever modules they wish regardless of what programme they are enrolled on. Characterised by self-selection, with no strict academic selection, it is close to the principle of the 'gap year' practiced in the US (Snee 2014) - but also youth mobility from Europe to Northern America, with the J-1 for instance. It offers students interested in leisure or self-development an academic justification to travel.

Finally, the 'mass participation model' is thus called for its capacity to quickly increase outgoing numbers, by making the exchange mandatory while loosening the language or module requirements - thus allowing students with no second language, or who study courses for which no equivalent is readily available, to have an 
academic justification for their year abroad; in addition to facilitating the work of academic and administrative staff on both sides of the exchange. As already noted, it is a coercive model, which may come with a range of justifications, the most suited being perhaps the pervasive discourse of 'employability'.

This categorisation is based on ideal-types, which may not exist in their exact form. Thus, in Ireland, the study did not bring up significant evidence of the 'original model' being in use; except for a handful of courses where such a model was in place due to the direct (and in some cases, forceful) involvement of individual faculty members.

The 'elite programme model' is visible in certain programmes such as International Business and Languages, European Studies or Law and Languages. These may not be socially elite but tend to be academically oriented programmes with a strong link between disciplinary identity and outward mobility to the country of the target language. Study abroad has been embedded in most of these programmes but they take the shape of a four-year degree (which may add to their perceived value, and turn away students with limited financial means). Faculty involvement remains strong; and the module match is monitored closely. In one Faculty of Business, staff check carefully that students are enrolled on the right courses, at the right level, in the right language, even if similar modules are available in English at the host university. These practices contrast sharply with those observed where the last two models are in place.

The gap year model and the mass model have already been described with the examples of the 'BA international' in UCD and MU on the one hand (voluntary participation, flexible choice of modules), and the mandatory exchange in UL on the other (mandatory participation). Erasmus is well suited to these models given the 
availability of places and the relative affordability of the year abroad under this scheme, which allows less privileged students to participate.

Modern Languages would be located either in the elite programme or in the mass participation model, depending on a number of factors. Applying a direct module match model is problematic as students of French for instance are in effect learners of French as a foreign language. Their courses include French history and Literature, but a year 3 course in French history, in a department of history in France, would be of a very different nature to what students study in Ireland for this particular subject. Students may therefore be allowed to study related modules at a lower level, or different courses altogether.

Non-EU exchange programmes may draw from the elite programme model as well as from the gap year model, but not from the other two. These are academically selective, because Irish universities, as sending institutions, are positioned differently vis-a-vis their oversea partners compared to their Erasmus partners: International university partnerships are based on 'selective affinities', with the more prestigious Irish HEIs more likely to be partnered with prestigious universities abroad compared to their less prestigious counterparts (Courtois 2017; Ballatore \& Blöss 2008). On a global scale, Ireland is dominated by the bigger English-speaking nations and in particular, those where the top 'world-class' universities are located - namely the UK, the US and to a lesser extent Canada and Australia. These destinations offer limited places and are selective as the logic of institutional prestige comes into play. For one such destination, an academic coordinator explained that they would only send 'elite' students, for this was an 'elite' destination. The application process is highly formalised and requires that applicants justify their module choices, thus mobilising their academic capital. Non-EU destinations are not only academically but also 
economically selective: Students are not entitled to the Erasmus grant and incur higher costs (flights, visas, compulsory medical insurance).

The gap year and mass participation models are the most likely to contribute efficiently to the 'massification' of the year abroad - understood as a shift from elite to mass participation. The next section turns to the discernible signs of an emerging horizontal stratification and its implications for students across a range of dimensions.

\section{Massification and differentiation of exchange programmes: Implications for quality and equality}

In a context where the focus is on increasing outward mobility quantitatively, institutions tend to present all types of outgoing mobility and destinations as equally beneficial, and to place the emphasis on lifestyle and employability. Thus, the following advice is given to students:

These skills are hard-wired into each Erasmus and Study Abroad programme, so for a student thinking about doing a year abroad it's comforting to know that it doesn't really matter which university you attend or which subject(s) you study while abroad (University website).

Most universities offer a small number of places on exchange programme with prestigious 'world-class' universities, as well as places in much less-known places . Yet the differentiated statuses of destinations are obscured by a discourse that focuses on individualism and the rhetoric of choice, as well as on the supposedly homogeneously beneficial effects of credit mobility under the gaze of the imagined future employer. The academic aspect is devalued, obscured by a focus placed instead on employability and lifestyle. In line with this institutional discourse, two international officers, interviewed separately, attributed students' complaints to their lack of open-mindedness and/or excessive academic focus. One officer reported 
emphatically telling students to "stop comparing!", while another suggested that those who were less likely to complain were those who "were thinking outside the box" by contrast to those who were "too focused on grades". Thus, in practice, students are asked to suspend their judgment of the quality of the educational experience and to focus on the social and professional value of their year abroad.

The extension of outgoing mobility through the 'mass participation model' and the 'gap year model', where the emphasis on module match and by extension, academic value, is reduced, opens the door to a number of issues. The first of these issues is the quality of the student experience in the area of teaching and learning. Serious issues were reported by students across the sample. While other issues also came up (difficulties with the language, accommodation issues, financial problems, isolation, boredom), criticism was often directed to the academic aspect of the experience and in particular module choice and teaching.

Upon arriving at their destination, some students found that the modules they were supposed to take were not available, either because they were reserved to local students and fee-paying non-EU students (such a 'pecking order' was noted by a participant) or because the host university communicated incorrectly. This specific issue came up repeatedly and is unlikely to be a matter of negligence on the part of all the students affected. A related issue was that modules were delivered as planned, but that they turned out to be at the wrong level for the student: either too easy (in particular, modules set up specifically for Erasmus students, where native Englishspeakers were at such an advantage that these modules presented no challenge at all) or too difficult (the opposite situation, where Erasmus students were expected to merge with local students and no provision was made for the fact they did not master 
the local language). Several students also reported that the local lecturers were hostile to them, turning them away from lectures or refusing to engage with them:

Many of the lecturers in the university did not welcome the Erasmus students and saw them as a hindrance. In the majority of the classes no exception was made for non-native speakers, we were usually marked the same as native speakers.

The vast majority of those who secured a place at a US or UK college reported having a very good educational experience. Mixed or negative experiences were reported by students who went to mainland Europe. What follows is a sample from the answers given by students in response to the questionnaire item on the academic benefits of the year abroad:

Yes, similar content but at a higher standard. (US)

Yes. My course in Ireland is very abroad so my year abroad helped me to focus specifically on film studies and US literature. The classes are also generally much smaller and topics are explored in more depth (UK).

No it was a joke like doing my junior cert again (Czech Republic)

No. Modules were unrelated to my studies at home, poorly graded and inefficient (Spain)

This should not be seen as a reflection of the 'quality' of education in these respective countries. As already stated, exchange with the US and UK is more closely monitored because they play a different role in universities' internationalisation processes. By comparison, fewer resources are dedicated to Erasmus students. ${ }^{6}$

As we know, some students choose to go abroad for leisure. To the same item, one such student responded: "Not academically, but we didn't care." In addition,

\footnotetext{
${ }^{6}$ One international officer remarked that outgoing Erasmus students were treated as 'second-class citizens' in the university, because scarce resources are focussed on the more prestigious and/or lucrative forms of exchange and incoming mobility.
} 
many who criticised the educational quality of the year abroad still found it had helped them in some way. This was the case of most language students, but also of a business student who said that he came back 'rested', like after a holiday, and ready to take on his final year. But a few students also felt that the year abroad was detrimental to their academic progress:

It has not helped me academically. I arrived in [town], and the ... department at the university informed me that no classes were in English. I had to look for classes in other departments, therefore ended up studying subjects I had no knowledge of. Now I will enter my final year at my home university with a year's gap in practice of writing essays, studying my own subjects.

In this sense, the fear of disruption identified by Beerken et al. (2016) as one of the significant barriers to participation, is justified. This other student also had a very negative view of his experience and its lasting consequences:

No. It has made me resent French, and I feel that it will take a long time for me to ever want to use French in my future career. If I could drop French at this stage in my course, I would. However, that is not possible for me, so I will finish studying it until the end of my degree, and then may never use it again.

In light of the serious organisational issues described by students across the sample, it seems that such negative experiences, although in a minority, should not be dismissed as caused by lack of adaptability or open-mindedness. These experiences have particular resonance when the objective costs of the year abroad are considered.

The grant I was offered covered very little of the stay, because my rent was so expensive, and I had a lot of money worries and stress caused by lack of money.

Although I really enjoyed my time in [country] it was a big ask to make it compulsory. It is definitely more expensive than staying in UL and it also meant 
I had to give up my part time job which I didn't get back when I was back in Ireland.

Typically, international officers, academic staff (and many students) stated that student dissatisfaction was due to a lack of open-mindedness or adaptability. This view ignores not only the organisational issues mentioned above, but also the socioeconomic differences that generate different abilities and ways to be mobile. Foskett (2010) thus discerns the emergence of a 'top tier' globally mobile student elite, unaffected by issues of tuition fees, language or travel costs, who aim for the best destinations. Brooks and Waters (2014) have also described these elite students as unaffected by what can be viewed as instrumental, cost-benefit considerations. The second tier consist of students who calculate costs and benefits and hope to improve their employment prospects by making the significant investment of studying abroad. Below is a third tier of students who are not mobile or if mobile limited to neighbouring and low-cost destinations. For these last two categories, the destination and the quality of the experience matter, since the time and financial investment is relatively higher compared to more privileged students. Less privileged students are also less likely to be at ease when the rules of the academic 'game' are changed and when non-academic types of capital (sociability, adaptability, distance from academic norms) need to be mobilised (Bathmaker, Ingram \& Waller 2013).

The negative accounts quoted above can be contrasted with that of other students who, on the other hand, enjoyed great benefits across different dimensions (academic, lifestyle, credentials):

It's a really highly ranked engineering college, and the location is amazing. Wanted to live beside the coast, also Santa Barbara has excellent year round weather and is centrally located in California, allowing for extensive travel (US). 
I've been told by my current $\mathrm{PhD}$ supervisor that my year abroad was crucial to the success of my application as they hadn't really heard much about [home university] so couldn't judge if grades were inflated or deflated in comparison to other universities. Having the benchmark of a prestigious internationally recognised university gave weight to my [home university] grades and experience (US, now enrolled full-time in a 'world-class' university).

Students constrained in their choices by financial considerations, or not given a choice (one explained his choice as follows: "Best out of terrible options") are not in a position to access the benefits offered to the few who are positioned in such a way that they can navigate the institutional frameworks and access more beneficial types of exchange. These contrasted experiences indicate that credit mobility offers another access to the global higher education market and some of its benefits, offering some "a second chance at success" (Brookes \& Waters 2009, in relation to privileged UK students enrolling in US universities). In the same way as the global market for degree mobility, the space of credit mobility is a narrower but nonetheless stratified space, where strategies can be deployed by those who are more privileged than others.

\section{Conclusion}

Exchange destinations are becoming stratified under the combined pressures of 'exchange massification' and budget restrictions at university level. The stratification between prestigious destinations, within exchange schemes established for prestige on the one hand, and new Erasmus destinations established to absorb increased outgoing numbers on the other, broadly overlaps with a differentiation in how the year abroad is organised and managed at institutional level. The emergent 'gap year model' and 'mass participation model' are better suited to a massification of exchange but are characterised by a lesser emphasis on module match and academic supervision, which 
is in turn justified by a discursive emphasis on lifestyle and employability. The gapyear model amplifies self-selection issues, while the coercive mass participation model ignores students' differential personal situations and pushes the less privileged towards less desirable and beneficial options.

The 'massification of exchange' is not dissimilar from the massification of Higher Education systems: Under the current circumstances, it tends to worsen social inequality in access to the most valuable positional opportunities (Marginson 2016). Thus, the tiers identified by other researchers in relation to degree mobility (e.g. Brookes \& Waters 2009) may be identified, on a smaller scale, within credit mobility. Pedagogic as well as formative opportunities may be lost when exchange is dissociated from its academic content and reduced to 'mobility for mobility's sake'. This may affect students differently depending on the types of capitals they are able to invest in their education. The 'de-academisation' of the year abroad can be understood as a side-effect of cost-cutting measures in the context of massification. It is also consistent with broader shifts in the missions of universities, as higher education policy is increasingly driven by the demands of employers for a flexible, mobile workforce (Brown \& Tannock 2009, Li \& Lowe 2015). The Irish case is not unique, as universities in other countries are similarly pressured to increase outgoing numbers in order to comply with the missions assigned to them in the 'knowledge economy' (Ball 2012; Robertson 2010). This leaves open the question of practitioners and their role in shaping internationalising practices in the corporatised university. 


\section{References}

Ballatore, Magali. 2013. "The Erasmus Programme in France, Italy and the United Kingdom: Student Mobility as a Signal of Distinction and Privilege." European Educational Research Journal, 12 (4): 525-533.

Ballatore, Magali, and Thierry Blöss. 2008. "Le sens caché de la mobilité des étudiants Erasmus." [The hidden meaning of the mobility of Erasmus students] in Échanges et mobilités académiques: Quel bilan?, edited by Fred Dervin and Michael Byram, 17-42. Paris: L'Harmattan.

Ball, Stephen. 2012. Global Education Inc.: New Policy Networks and the Neo-liberal Imaginary. London and New York: Routledge.

Bathmaker, Ann-Marie, Nicola Ingram, and Richard Waller. 2013. "Higher Education, Social Class and the Mobilisation of Capitals: Recognising and Playing the Game." British Journal of Sociology of Education, 34 (5-6): 723 743.

Beech, Suzanne. 2014. "International Student Mobility: The Role of Social Networks." Social and Cultural Geography, 16 (3): 332-350.

Beerkens, Maarja, Manuel Souto-Otero, Hans de Wit, and Jeroen Huisman. 2016. "Similar Students and Different Countries? An Analysis of the Barriers and Drivers for Erasmus Participation in Seven Countries." Journal of Studies in International Education, 20 (2): 184-204.

Brooks, Rachel, and Johanna Waters. 2009. "A Second Chance at 'Success': UK Students and Global Circuits of Higher Education." Sociology, 43 (6): 10851102.

Brooks, Rachel, and Johanna Waters. 2014. Student Mobilities, Migration and the Internationalisation of Higher Education. Basingtoke: Palgrave Macmillan.

Brooks, Rachel, Johanna Waters, and Helen Pimlott-Wilson. 2012. "International Education and the Employability of UK Students." British Educational Research Journal, 38 (2): 281-298.

Brown, Philip, and Stuart Tannock. 2009. "Education, Meritocracy and the Global War for Talent." Journal of Education Policy 24 (4): 377-392.

Courtois, Aline. 2016. "Internationalising Practices and Representations of the 'Other' in Second-level Elite Schools in Ireland." Globalisation, Societies and Education 14 (4): 560-576.

Courtois, Aline. 2017. "The Global Ambitions of Irish Universities: Internationalising Practices and Emerging Stratification in the Irish Higher Education Sector." In Universities and the Production of Elites: Discourses, Policies, and Strategies of Excellence and Stratification in Higher Education, edited by Roland Bloch, Alexander Mitterle, Catherine Paradeise and Tobias Peter. Basingstoke: Palgrave Macmillan.

Courtois, Aline, and Theresa O'Keefe. 2015. "Precarity in the Ivory Cage: Neoliberalism and Casualisation of Work in the Irish Higher Education Sector." Journal of Critical Education Policy Studies 13 (1): 43-66.

EC (European Commission). 2011. "Erasmus for all: The EU Programme for Education, Training, Youth and Sport." COM (2011) 787 final. Communication from the Commission to the European Parliament, the 
Council, the European Economic and Social Committee and the Committee of the Regions. Retrieved from http://eur-lex.europa.eu/legalcontent/EN/TXT/?uri=COM:2011:0787:FIN

EC (European Commission). 2015. "Erasmus+ Programme Annual Report 2015, Annex 1." EU Publication Office. Retrieved from

https://ec.europa.eu/programmes/erasmus-

plus/sites/erasmusplus/files/erasmus-plus-annual-report-2015-annex-1 en.pdf, 9 March 2017.

Erlich, Valérie (2012). Les Mobilités étudiantes [Student mobilities]. Paris: La documentation française.

Fernex, Alain, Erica de Vries, and Laurent Lima. 2017. "Articulating Perspectives on International and Social Mobility in Higher Education. ” European Journal of Higher Education, 7 (1): 3-14.

Foskett, Ros. 2010. Capacity Building for Demography in Southern Africa: International Collaboration in Action. In Globalization and Internationalization in Higher Education: Theoretical, Strategic and Management Perspectives. London: Bloomsbury.

Gerhards, Jürgen, and Silke Hans. 2013. "Transnational Human Capital, Education and Social Inequality: Analyses of International Student Exchange." Zeitschrift fur Soziologie, 42 (2): 99-117.

Hadfield, Amelia, and Robert Summerby-Murray. 2016. "Vocation or Vocational? Reviewing European Union Education and Mobility Structures." European Journal of Higher Education, 6 (3): 237-255.

Khoo Su-Ming. 2011. "Ethical Globalisation or Privileged Internationalisation? Exploring Global Citizenship and Internationalisation in Irish and Canadian Universities." Globalisation, Societies and Education, 9 (3-4): 337-353.

Kim, Jongyoung. 2015. "Global Cultural Capital and Global Positional Competition: International Graduate Students' Transnational Occupational Trajectories." British Journal of Sociology of Education, 37 (1): 30-50.

Knight, Jane. 2006. Internationalisation: Concepts, Complexities and Challenges. In International Handbook of Higher Education, edited by J. Forest and P. G. Altbach, 207-227. Dortrecht: Springer.

Li, Zhen, and John Lowe. 2015. "Mobile Student to Mobile Worker: The Role of Universities in the 'War for Talent"'. British Journal of Sociology of Education, 37 (1): 11-29.

Lynch, Kathleen. 2015. "Control by Numbers: New Managerialism and Rankings in Higher Education." Critical Studies in Education, 56 (2): 190-207.

Marginson, Simon. 2016. "High Participation Systems of Higher Education." The Journal of Higher Education, 87 (2): 243-270.

Matus, Claudia, and Susan Talburt. 2009. "Spatial Imaginaries: Universities, Internationalisation and Feminist Geographies." Discourse: Studies in the Cultural Politics of Education, 30 (4): 515-527.

Netz Nicolai, and Claudia Finger. 2016. "New Horizontal Inequalities in German Higher Education? Social Selectivity of Studying Abroad between 1991 and 2012." Sociology of Education, 89 (2): 79-98.

Nørgaard, Thomas. 2014. "Liberal Education in the Erasmus Programme.” In Internationalisation of Higher Education and Global Mobility, edited by Bernhard Streiweiser, 99-118. Oxford: Symposium Books.

Paradeise, Catherine, and Jean-Claude Thoenig. 2015. In Search of Academic Quality. Basingstoke: Palgrave Macmillan. 
Robertson, Susan. 2010. "Corporatisation, Competitiveness, Commercialization: New Logics in the Globalizing of UK Higher Education." Globalisation, Societies and Education, 8 (2): 191-203.

Rivzi, Fazal. 2011. Theorizing Student Mobility in an Era of Globalization. Teachers and Teaching: Theory and Practice, 17 (6): 693-701.

Rodríguez González, Carlos, Ricardo Bustillo Mesanza, and Pter Mariel. 2011. "The Determinants of International Student Mobility Flows: An Empirical Study of the Erasmus Programme." Higher Education, 62 (4): 413-430.

Sidhu, Ravinder. 2006. Universities and Globalization: To Market, to Market. Mahwah: Laurence Erlbaum.

Snee, Helene. 2014. A Cosmopolitan Journey? Difference, Distinction and Identity Work in Gap Year Travel. Farham and Burlington: Ashgate.

Stensaker, Bjørn, Nicoline Frølich, Åse Gornitzka, and Peter Maassen. 2008. "Internationalisation of Higher Education: The Gap between National Policymaking and Institutional Needs." Globalisation, Societies and Education, 6 (1): 1-11.

Turner, Yvonne, and Sue Robson. 2008. Internationalizing the University. London, UK: Continuum International.

Van Bouwel, Linda and Reinhilde Veugelers. 2013. "The Determinants of Student Mobility in Europe: The Quality Dimension." European Journal of Higher Education, 3 (2): 172-190.

Wächter, Bernd. 2014. "Recent Trends in Student Mobility in Europe." In Internationalisation of Higher Education and Global Mobility, edited by Bernhard Streitwieser, 87-98. Oxford: Symposium Books.

Waters, Johanna, and Rachel Brooks. 2010. "Accidental Achievers? International Higher Education, Class Reproduction and Privilege in the Experiences of UK Students Overseas." British Journal of Sociology of Education, 31 (2): 217228. 